\title{
Changes in Spores of Clostridium bifermentans Caused by Treatment with Hydrogen Peroxide and Cations
}

\author{
By W. M. WAITES, LINDA R. WYATT, N. R. KING \\ AND CATHERINE E. BAYLISS \\ Agricultural Research Council Food Research Institute, Colney Lane, \\ Norwich NR4 7 UA
}

(Received I5 September 1975)

\begin{abstract}
SUMMARY
Spores of Clostridium bifermentans were treated with hydrogen peroxide until their peripheries had lost refractility. The centres of such spores only retained refractility at acid $\mathrm{pH}$. Adding monovalent cations or increasing the $\mathrm{pH}$ caused the treated spores to lose their remaining refractility and decreased the turbidity of spore suspensions. Divalent cations prevented or reversed this loss of central refractility and decreased the fall in turbidity. Calcium ions also prevented but did not reverse the loss of central refractility which occurred on drying or applying pressure. Electron micrographs of spores treated with hydrogen peroxide showed that the cortex was depleted or absent and that the loss of central refractility was accompanied by protoplast swelling. It is suggested that divalent cations make spores resistant to drying and pressure by cross-linking negatively charged groups within the protoplast, and that together with hydrogen ions they neutralize the negatively charged groups, thus preventing the swelling of the protoplast, loss of refractility and fall in extinction which occur when divalent cations are replaced by monovalent cations.
\end{abstract}

\section{INTRODUCTION}

Warth, Ohye \& Murrell $(1963 a, b)$ suggested that divalent cations, such as calcium, help to maintain the structure of a bacterial endospore by cross-linking carboxyl groups in the spore cortex, and so give it the contractile properties proposed by Lewis, Snell \& Burr (I960). Calcium ions may also stabilize the membranes of spore protoplasts (Fitz-James, I971; Ellar, Eaton \& Posgate, I974). Monovalent cations such as sodium or potassium are generally required for the germination of spores, and an increase in the level of free ions within spores may be one of the first events in the initiation of germination (Gould \& Dring, I972). During germination, potassium ions are taken up by spores of Bacillus subtilis (Dring \& Gould, I97I) and calcium ions are lost (Powell \& Strange, I953) but there is no direct evidence to indicate the site of these changes or their role in germination. During a study of the effect of hydrogen peroxide on spores of Clostridium bifermentans we noticed that the addition of sodium phosphate buffer $\mathrm{pH} 8.0$ to peroxide-treated spores resulted in a loss of spore refractility and a decrease in turbidity of the spore suspension. Such changes usually occur during the germination of untreated spores, which requires organic media in addition to sodium ions. We have therefore studied the effect of changes in sodium and hydrogen ion concentrations on spores which have been treated with hydrogen peroxide. 

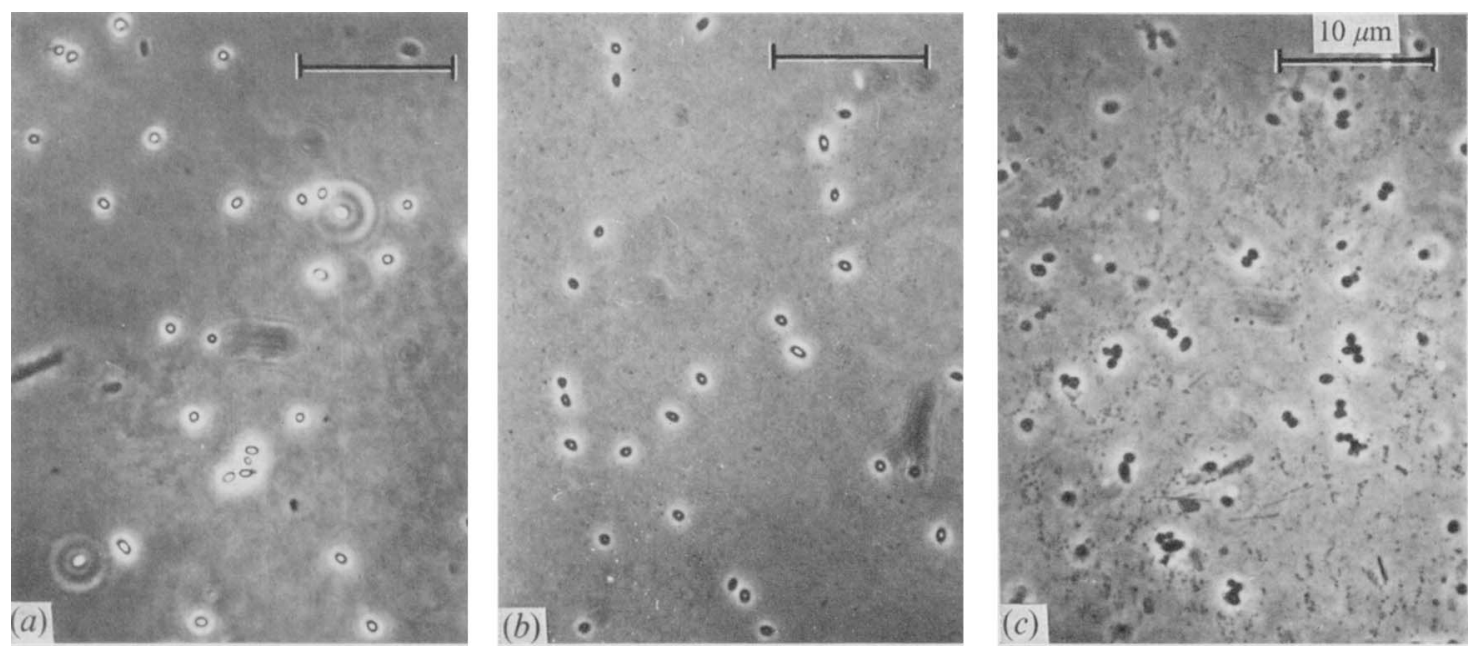

Fig. I. Effect of hydrogen peroxide on the refractility of spores of $C$. bifermentans. Phase-contrast photographs show $(a)$ untreated, dormant spores; $(b)$ spores after treatment with $\mathrm{H}_{2} \mathrm{O}_{2}$ and fixing in $25 \%(\mathrm{v} / \mathrm{v})$ glutaraldehyde to prevent loss of refractility during drying; $(c)$ peroxide-treated spores after addition of $240 \mathrm{mM}-\mathrm{NaCl}$.

\section{METHODS}

Organisms, spore preparation and maintenance of culture. The strain of Clostridium bifermentans used and the preparation and storage of spores have been described previously (Waites \& Wyatt, 197I). The organism was maintained in the reinforced clostridial medium of Hirsch \& Grinsted (1954).

Spore dry weight. Dry weights were measured spectrophotometrically using a calibration curve relating $E_{600}$ to spore dry weight.

Treatment of spores with hydrogen peroxide. Spores (I5 $\mathrm{mg}$ dry wt) were incubated in $\mathrm{I} \cdot \mathrm{O} \mathrm{ml}$ of hydrogen peroxide solution $(8.5 \mathrm{M})$ at 20 to $24{ }^{\circ} \mathrm{C}$ for $9 \mathrm{~h}$, until the outer regions of the spores had lost refractility and the centres had become dull but still refractile when examined with a phase-contrast microscope (Fig. I). Suspensions in which $40 \%$ or more of the spores failed to lose this central refractility within $10 \mathrm{~min}$ of transferring into $50 \mathrm{~mm}$ $\mathrm{NaCl}$ were again treated with $\mathrm{H}_{2} \mathrm{O}_{2}$ for 2 to $3 \mathrm{~h}$. Treated spores were washed four times by centrifuging at $4{ }^{\circ} \mathrm{C}$ in glass-distilled water and adjusted to $\mathrm{pH} 3.8$ with $0 . \mathrm{I} \mathrm{M}-\mathrm{HCl}$, before resuspension and storage in $2 \mathrm{ml}$ acidified glass-distilled water in polypropylene centrifuge tubes. Such spores retained central refractility for at least 8 weeks when stored at $0{ }^{\circ} \mathrm{C}$, but about $40 \%$ of spores stored in glass-distilled water at $\mathrm{pH} 6.5$ in glass vessels or at a concentration of less than $7 \mathrm{mg}$ dry $\mathrm{wt} / \mathrm{ml}$ lost central refractility in 8 weeks.

Measurement of loss of refractility and decrease in turbidity. Spore suspensions, at a final concentration equivalent to about $40 \mu \mathrm{g}$ dry wt $/ \mathrm{ml}$, were incubated at $37^{\circ} \mathrm{C}$ in $2.5 \mathrm{ml}$ glass-

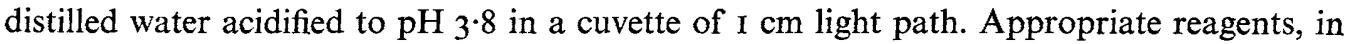
a volume of $0.3 \mathrm{ml}$, were added without shaking and the decrease in turbidity at $600 \mathrm{~nm}$ recorded spectrophotometrically. Loss of the central refractility was measured under similar conditions by counting 100 spores using a phase-contrast microscope, and scoring semi-refractile (i.e. refractile in the centre but with a non-refractile periphery) or nonrefractile spores. Spores which remained wholly refractile after the peroxide treatment (less than $10 \%$ of the population) were scored as semi-refractile. The standard deviation between 
duplicate counts was less than $5 \%$ and in separate experiments with the same spore preparation was less than $10 \%$. After each incubation the $\mathrm{pH}$ value was measured with a glass electrode.

Preparation of samples for microscopy. For phase-contrast photographs spore suspensions were dried on to coverslips which were placed on slides coated with agar. Spores treated with hydrogen peroxide were fixed with $25 \%$ glutaraldehyde to prevent any loss of their remaining refractility during drying. For electron microscopy spore suspensions were fixed and embedded as described previously (Waites, Wyatt \& Arthur, 1972).

Measurement of germination rate. Germination of untreated spores was followed spectrophotometrically at $37^{\circ} \mathrm{C}$ by measuring the decrease in $E_{600}$ as described by Waites \& Wyatt (I97I). Germination media were (mM): the 'Ala +' system, containing L-alanine (50), L-arginine (5), L-phenylalanine (5), L-lactate (25), $\mathrm{NaCl}$ (100) and potassium phosphate (83), $\mathrm{pH} 7.5$; or the 'Gly + ' system which was the 'Ala + ' system with potassium phosphate (83) at $\mathrm{pH} 6.25$ and with glycine (25) replacing L-alanine. The potassium phosphate buffer was $\mathrm{KH}_{2} \mathrm{PO}_{4}$, adjusted to $\mathrm{pH} 7 \cdot 5$ with potassium hydroxide, and adjusted to a final concentration of $83 \mathrm{~mm}$-potassium in the medium.

Polyacrylamide gel electrophoresis. Hydrogen peroxide extracts were dialysed against glass-distilled water and then concentrated by vacuum dialysis. Extracts containing $100 \mu \mathrm{g}$ protein in $0.2 \mathrm{ml}$ were added to polyacrylamide gels $(7.5 \%, \mathrm{pH} 8.5)$ and electrophoresis carried out as described previously (Wyatt \& Waites, I97I).

Measurement of dipicolinic acid, calcium and glucosamine. Dipicolinic acid was measured by the method of Janssen, Lund \& Anderson (1958) using a solution of dipicolinic acid (Koch-Light) as a standard. Calcium was extracted by the wet ashing procedure of Slepecky \& Foster (1959) and estimated in the presence of lanthanum chloride by atomic absorption spectrophotometry at $422 \mathrm{~nm}$ with a Unicam SP $900 \mathrm{~A}$ as described by Linehan (I966) and Haworth \& Cleaver (196I). Glucosamine was measured by the method of Rondle \& Morgan (I955), after hydrolysis in $6 \mathrm{M}-\mathrm{HCl}$ at $100^{\circ} \mathrm{C}$ for $5 \mathrm{~h}$ (Vary, I973), using $\mathrm{D}(+)$-glucosamine hydrochloride (Sigma) as a standard.

\section{RESULTS}

\section{Effect of cations and $p H$ on the refractility and turbidity of spores after treatment} with hydrogen peroxide

Spores treated with $\mathrm{H}_{2} \mathrm{O}_{2}$ were incubated at $37{ }^{\circ} \mathrm{C}$ and the effect of a number of additions on the turbidity and refractility determined as described in Methods. Addition of $0.3 \mathrm{ml}$

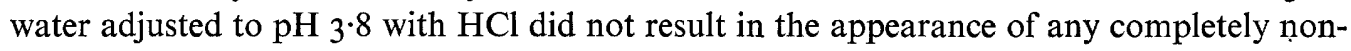
refractile spores and the $10 \%$ immediate decrease in turbidity due to dilution, did not increase further by $20 \mathrm{~min}$ (Fig. 2). Addition of $2 \mathrm{M}-\mathrm{NaCl}$ or $2 \mathrm{M}$-tris- $\mathrm{HCl}$ buffer $\mathrm{pH} 8 \cdot 0$, to give a final concentration of $100 \mathrm{mM}$, increased the $\mathrm{pH}$ to 4.8 or 7.8 respectively and resulted in a rapid loss of refractility from the centre of the spores (Fig. I). Loss of central refractility occurred in more spores after the addition of $\mathrm{NaCl}$ than after the addition of the same concentration of tris- $\mathrm{HCl}$; in contrast, the fall in turbidity was always greater after the addition of tris $-\mathrm{HCl}$ than after the addition of $\mathrm{NaCl}$ (Fig. 2). Addition of sodium phosphate buffer $\mathrm{pH} 8 \cdot 0$, to a final concentration of $100 \mathrm{~mm}$ in both sodium and phosphate, resulted in a rapid fall in turbidity and loss of refractility. The presence of $0.5 \mathrm{M}$-sucrose, which prevents lysis of spheroplasts of Clostridium butyricum (Kawata \& Inoue, I963), failed to prevent either change, suggesting that they were not produced by lysis of the protoplast. It appeared that the fall in turbidity was produced by the $\mathrm{pH}$ change, while the rapid loss of 


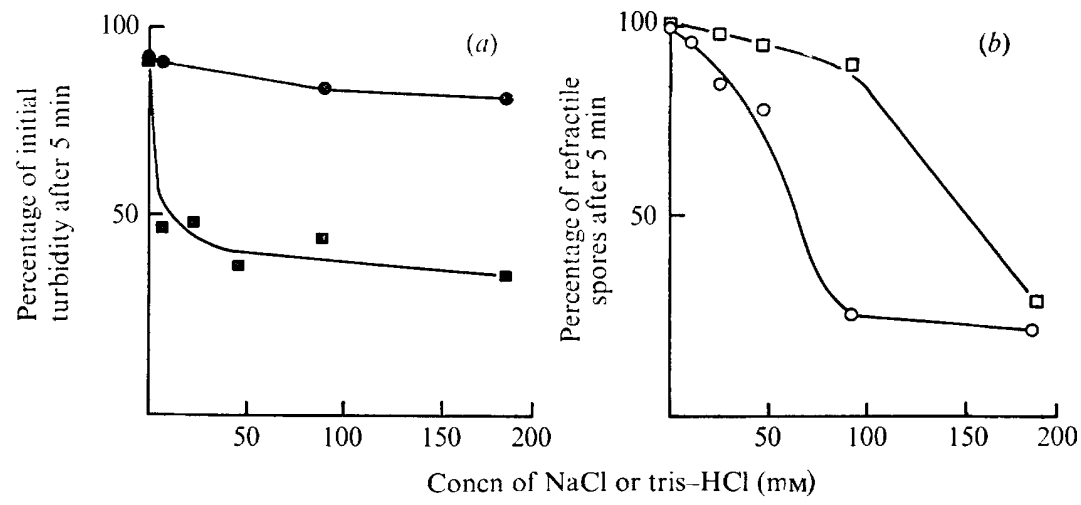

Fig. 2. Effect of $\mathrm{NaCl}$ or tris-HCl buffer on refractility and turbidity of spores treated with $\mathrm{H}_{2} \mathrm{O}_{2}$. Peroxide-treated spores were incubated at $37^{\circ} \mathrm{C}$ as described in Methods, $\mathrm{NaCl}(\mathrm{O}$, $\bigcirc)$ or tris$\mathrm{HCl}$ buffer $\mathrm{pH} 8 \cdot 0(\square, \mathbf{E})$ was added and $(a)$ the decrease in turbidity (closed symbols) and $(b)$ the loss of central refractility (open symbols) were detected by spectrophotometry and phasecontrast microscopy respectively.

\section{Table I. Stimulation of germination of spores of C. bifermentans by monovalent cations}

Spore suspensions were incubated at $37^{\circ} \mathrm{C}$ with the 'Ala + ' or ' $\mathrm{Gly}+$ ' systems and I00 mM of sodium, potassium, lithium or ammonium chloride either with or without potassium phosphate buffer, as described in Methods. Germination was measured spectrophotometrically and the germination rate is calculated from the maximum rate of decrease in $E_{600}\left(\right.$ in $\left.\min ^{-1}\right)$, expressed as a percentage of the initial $E_{600}$ value.

\begin{tabular}{|c|c|c|c|c|}
\hline \multirow[b]{3}{*}{ Added chloride } & \multicolumn{4}{|c|}{ Germination rate $\left(\% \min ^{-1}\right)$} \\
\hline & \multicolumn{2}{|c|}{ 'Ala +' } & \multicolumn{2}{|c|}{ 'Gly +' } \\
\hline & + Buffer & - Buffer & + Buffer & - Buffer \\
\hline None & 23 & $4 \cdot 2$ & 6.6 & $<0.2$ \\
\hline Sodium chloride & 77 & 86 & 22 & 30 \\
\hline Potassium chloride & 55 & 46 & I4 & $I \cdot 6$ \\
\hline Lithium chloride & 44 & 43 & $9 \cdot 2$ & $I \cdot 7$ \\
\hline Ammonium chloride & 44 & $2 I$ & $7 \cdot 5$ & $<0.2$ \\
\hline
\end{tabular}

refractility was initiated by sodium ions. However, other cations could replace sodium as 5 min incubation with sodium, potassium, lithium or ammonium chloride at $24 \mathrm{~mm}$ (the concentration at which the greatest differences between the different cations occurred) produced loss of refractility in $59,36,30$ or I I \% of spores respectively.

Germination of untreated spores of $C$. bifermentans requires sodium ions, although with some germination media potassium ions can substitute with a reduced efficiency (Waites \& Wyatt, 197I). The germination rates of untreated spores with sodium, potassium, lithium or ammonium chloride showed a similar descending order (Table I) to the effects obtained with treated spores.

Hitchins \& Gould (I964) isolated refractile 'cores' from spores of Bacillus subtilis; these 'cores' were stable at acid $\mathrm{pH}$ but lost refractility if the $\mathrm{pH}$ was increased to $7^{\circ} \mathrm{O}$ unless calcium chloride was present. The presence of $\mathrm{CaCl}_{2}$ markedly reduced the percentage of peroxide-treated spores which lost central refractility (Fig. 3), and at $90 \mathrm{~mm}$ also reduced the fall in turbidity from 55 to $35 \%$ after the addition of $100 \mathrm{mM}$-tris-HCl. Calcium, barium 


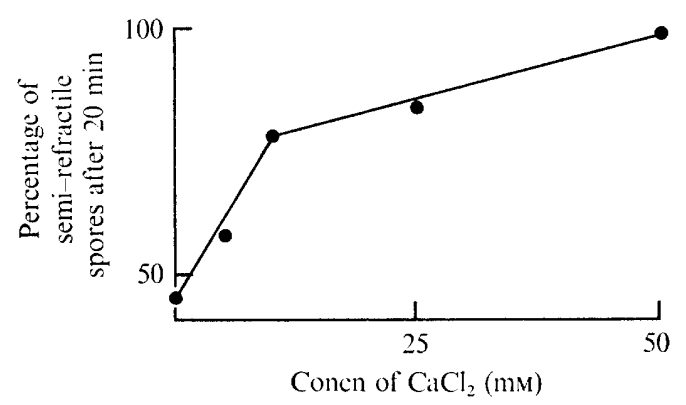

Fig. 3. Effect of calcium chloride on the loss of refractility initiated with $\mathrm{NaCl}$ in spores treated with $\mathrm{H}_{2} \mathrm{O}_{2}$. Spores treated with $\mathrm{H}_{2} \mathrm{O}_{2}$ were incubated at $37^{\circ} \mathrm{C}$ with the concentrations of $\mathrm{CaCl}_{2}$ described, $\mathrm{NaCl}$ (I $86 \mathrm{~mm}$ ) was added, and the loss of central refractility was determined by phasecontrast microscopy.

or magnesium chloride $(50 \mathrm{~mm})$ reduced the percentage of peroxide-treated spores which lost central refractility after the addition of $200 \mathrm{mM}-\mathrm{NaCl}$ from $58 \%$ to 5 , 18 or $46 \%$ respectively. Addition of $\mathrm{CaCl}_{2}$ to peroxide-treated spores which had lost central refractility in the presence of $\mathrm{NaCl}$ caused about half to regain refractility, but spores which had lost refractility on drying or applying thumb pressure to the coverslip were unable to regain refractility. The presence of $\mathrm{CaCl}_{2}$ during drying or applying pressure prevented loss of refractility.

\section{Structure of spores after treatment with hydrogen peroxide}

In electron micrographs of thin sections of peroxide-treated spores the spore cortex was depleted or in some preparations removed completely (Fig. $4 a, b$ ). In addition, the electron density of the coat was decreased and the ribosomes in the protoplast appeared disordered compared with untreated spores. Addition of sodium and then calcium ions to peroxidetreated spores resulted in swelling (Fig. $4 c$ ) and then contraction of the protoplast (Fig. $4 d$ ).

Polyacrylamide gel electrophoresis of the supernatant from spores treated with $\mathrm{H}_{2} \mathrm{O}_{2}$ showed two bands, one of which had the same electrophoretic mobility as that removed from spore coats by $\mathrm{NaOH}$ (Wyatt \& Waites, I97I), while the other, more diffuse, band was less mobile. Calcium and dipicolinic acid were less than $0.1 \%$ of the dry weight of spores treated with $\mathrm{H}_{2} \mathrm{O}_{2}$, but were about $\mathrm{I} \cdot 2$ and $5 \%$ respectively of the dry weight of untreated dormant spores. Glucosamine was reduced from $2 \cdot 7 \%$ to between $\mathrm{I} \cdot 3$ and $0.9 \%$ of the dry weight by different treatments with $\mathrm{H}_{2} \mathrm{O}_{2}$.

\section{DISCUSSION}

In this study a series of changes, collectively resembling germination, have been produced in three stages in spores of $C$. bifermentans. The first stage, loss of peripheral refractility, was the result of incubation with $\mathrm{H}_{2} \mathrm{O}_{2}$. The second and third stages, loss of refractility in the remainder of the spore and a decrease in turbidity, were initiated by increasing the $\mathrm{pH}$ from 3.8 to 7.8 in the presence of sodium ions. These two stages could be partially separated

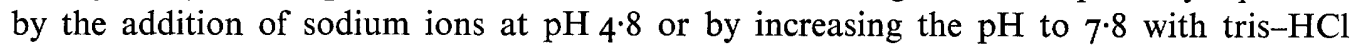
buffer. Other monovalent cations were less effective than sodium and were also less effective in stimulating the germination rate of untreated spores. Hitchins \& Gould (1964) isolated 'cores' from spores of $B$. subtilis by shaking in a Mickle disintegrator below $\mathrm{pH} 4 \cdot 2$. Such 'cores', which consisted of the spore protoplast and part of the cortex, lost refractility when the $\mathrm{pH}$ was raised to $7 \cdot 0$, but no decrease in turbidity or requirement for monovalent cations 

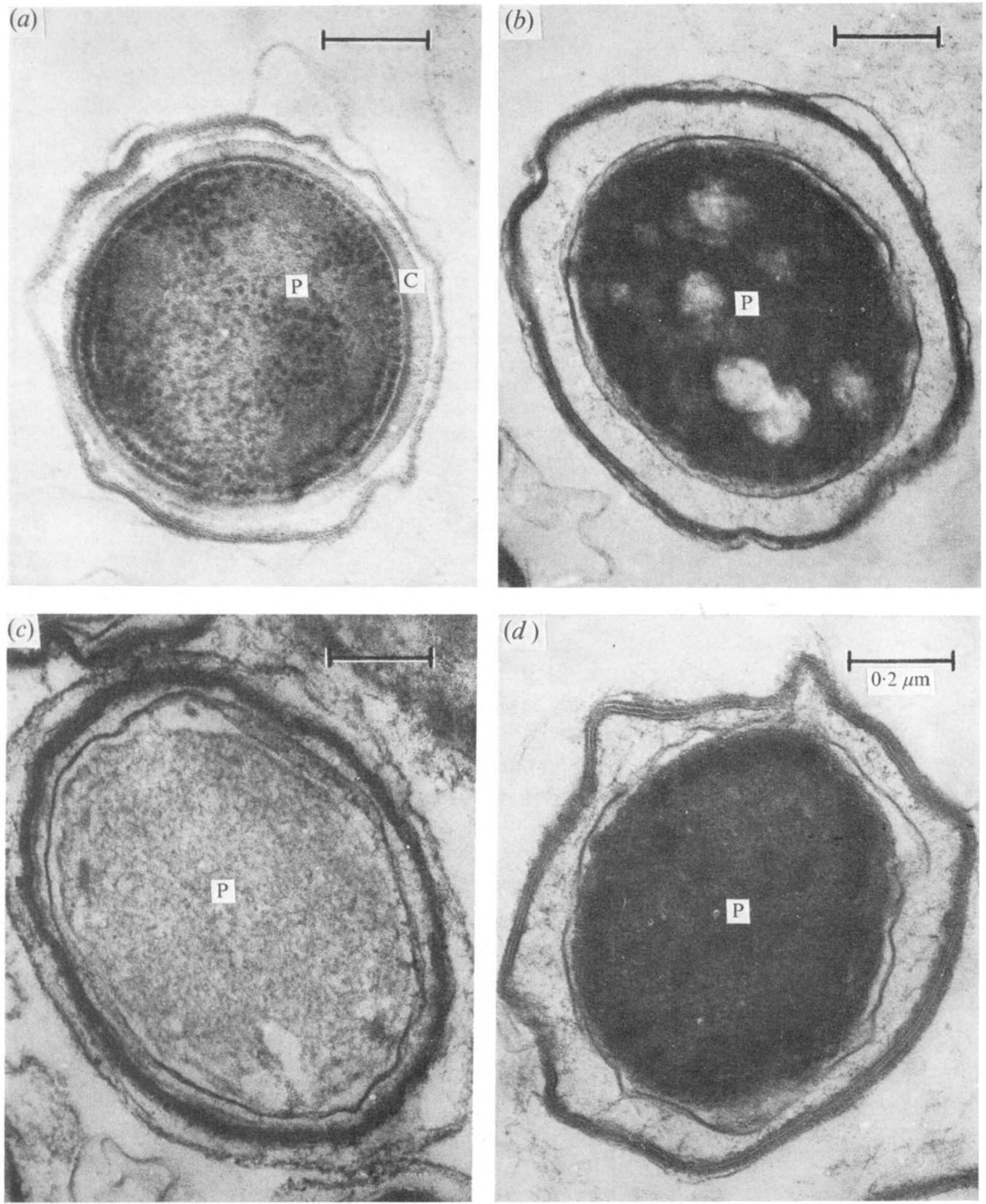

Fig. 4. Effect of sodium and calcium chloride on the ultrastructure of spores treated with $\mathrm{H}_{2} \mathrm{O}_{2}$. Electron micrographs show: thin sections of spores $(a)$ untreated and $(b)$ after treatment with $\mathrm{H}_{2} \mathrm{O}_{2} ;(c)$ treated spore after the addition of $240 \mathrm{mM}-\mathrm{NaCl} ;(d)$ treated spore after the addition of $240 \mathrm{mM}-\mathrm{NaCl}$ followed by $80 \mathrm{~mm}-\mathrm{CaCl}_{2}$. C, cortex; P, protoplast. 
was reported. Neither the 'cores' nor peroxide-treated spores were able to form colonies on agar growth media. In spores, glucosamine is present only in the cortex (Murrell, I969). Different peroxide treatments removed between 50 and $70 \%$ of the glucosamine from spore populations, and examination of electron micrographs of thin sections of peroxidetreated spores showed that some appeared to have lost all their cortex. If the cortex was completely removed, a contractile cortex as suggested by Lewis et al. (1960) cannot be responsible for the stability of the spore protoplast at acid pH. Moreover, Pearce \& FitzJames (197I) studied a mutant of Bacillus cereus whose spores had no cortex but showed central refractility only.

Calcium ions reduced the loss of refractility and fall in turbidity of peroxide-treated spores and also prevented loss of refractility of spore 'cores' (Hitchins \& Gould, I964) but did not inhibit germination of untreated spores or cause untreated germinated spores to regain refractility except at higher concentrations (Vinter, Štastná \& Č́slavská, I969; Sacks, I972; Hashimoto, Frieben \& Conti, 1969). Other divalent cations also reduced the loss of refractility from peroxide-treated spores. Calcium ions prevented the irreversible loss of refractility produced by drying or pressure and caused contraction of protoplasts swollen after addition of $\mathrm{NaCl}$. Hydrogen ions or cations inhibit the lysis of protoplasts made from vegetative bacterial cells (Edebo, I96r; Grula \& Hartsell, 1957) and lysis of growing clostridia by monovalent ions has been reported (Ogata \& Hongo, 1973), although in our experiments protoplast swelling, not lysis, occurred. Calcium accounts for about $2 \%$ of the dry weight of dormant spores (Murrell, I969) and it has been suggested that calcium ions may stabilize the cortical peptidoglycan (Warth et al., I963a,b) or the protoplast membrane of dormant spores (Fitz-James, I97I ; Ellar et al., I974). Spores treated with $\mathrm{H}_{2} \mathrm{O}_{2}$ lost nearly all their calcium and were unstable at neutral $\mathrm{pH}$ in the absence of added calcium or other divalent ions, suggesting that such ions help to stabilize dormant spores. The cortex appeared to be absent in electron micrographs of some peroxide-treated spores, and in such spores the added divalent ions could not act by stabilizing cortical material but might affect the protoplast membrane or the protoplast itself. As suggested by Hitchins \& Gould (1964), negatively charged groups in the dormant spore might be neutralized by hydrogen ions and neutralized and cross-linked by calcium ions. Removal of calcium ions would allow the spore to remain stable only at high concentrations of hydrogen ions. At higher $\mathrm{pH}$ there would be insufficient hydrogen ions to neutralize the negative charges and this would result in swelling of the spore protoplast, loss of refractility and spore material and a fall in turbidity. Addition of sufficient sodium ions to replace any remaining divalent ions would result in loss of cross-linkages and produce similar changes at $\mathrm{pH}$ values at which the negative groups are neutralized. The continued neutralization of negative groups might result in less severe changes in the spore so that a smaller loss of spore material and hence a smaller fall in turbidity would result. Calcium ions bound to membranes may be displaced by sodium or potassium ions (Rojas \& Tobias, 1965) and, for example, Ehrström et al. (I973) have shown that calcium ions confer rigidity on membranes isolated from vegetative cells of $B$. subtilis while monovalent ions like sodium have a negligible ordering effect and at high concentrations ( $\cdot \mathrm{I}$ to $\mathrm{I} \cdot \mathrm{O} \mathrm{M}$ ) cause disorganization. Joos \& Carr ( 1967 ) have also shown that in the physiological $\mathrm{pH}$ range, membranes containing phosphotidylserine, triphosphoinositide and phosphotidylethanolamine possess many calcium binding groups and can show large variations in bound ions with comparatively small $\mathrm{pH}$ changes, while Papahadjopoulos \& Ohki (1969) found that phospholipid membranes with calcium ions present on one side are stable only if the other side is lowered to $\mathrm{pH} 3{ }^{\circ} \mathrm{O}$.

During germination of untreated spores monovalent ions, like sodium, may act by 
replacing calcium ions at sensitive sites within the spore. Loss of divalent linkages and removal of the calcium ions by dipicolinic acid, as suggested by Gould \& Dring (1972), may then initiate germination.

We are grateful to Dr J. Payne and Dr J. L. Peel for useful discussions, Mr G. M. Wyatt for the phase-contrast photographs, Mr R. Faulkes for help with the calcium estimations and Miss Linda J. Nockolds for skilled technical assistance.

\section{REFERENCES}

DRING, G. J. \& Gould, G. W. (1971). Movement of potassium during L-alanine-initiated germination of Bacillus subtilis spores. In Spore Research-197I, pp. 133-I4I. Edited by A. N. Barker, G. W. Gould and J. Wolf. London: Academic Press.

EDEBo, L. (196I). Lysis of bacteria. III. On the stability of protoplasts and spheroplasts in different $\mathrm{pH}$ ranges. Acta pathologica et microbiologica scandinavica $53, \mathrm{I} 2 \mathrm{I}-\mathrm{I} 28$.

Ehrström, M., Eriksson, L. E. G., IsraelachViLI, J. \& Ehrenberg, A. (I973). The effects of some cations and anions on spin labelled cytoplasmic membranes of Bacillus subtilis. Biochemical and Biophysical Research Communications 55, 396-402.

Ellar, D. J., Eaton, M. W. \& Posgate, J. (1974). Calcium release and germination of bacterial spores. Biochemical Society Transactions 2, 947-948.

Fitz-JAMES, P. C. (197r). Formation of protoplasts from resting spores. Journal of Bacteriology 205, I I 19II36.

Gould, G. W. \& Dring, G. J. (1972). Biochemical mechanisms of spore germination. In Spores V, pp. 40I-408. Edited by H. O. Halvorson, R. Hanson and L. L. Campbell. Washington, D.C.: American Society for Microbiology.

Grula, E. A. \& Hartsell, S. E. (1957). Lysozyme in the bacteriolysis of Gram-negative bacteria. II. Factors influencing clearing during the Nakamura treatment. Canadian Journal of Microbiology 3, 23-34.

Hashimoto, T., Frieben, W. R. \& Conti, S. F. (1969). Microgermination of Bacillus cereus spores. Journal of Bacteriology 100, $1385-1392$.

Haworth, F. \& Cleaver, T. J. (I96I). Flame-photometric determination of calcium and magnesium in vegetables. Journal of the Science of Food and Agriculture 12, 848-852.

HIRSCH, A. \& GRINSTED, E. (1954). Methods for the growth and enumeration of anaerobic spore-formers from cheese, with observations on the effect of nisin. Journal of Dairy Research 21, I0I-I IO.

Hrtchins, A. D. \& GouLD, G. W. (1964). Release of cores from bacterial spores by mechanical breakage in acidic media. Nature, London 203, 895-896.

JANSSEN, F. W., Lund, A. J. \& ANDERSON, L. E. (1958). Colorimetric assay for dipicolinic acid in bacterial spores. Science, New York 127, 26-27.

Joos, R. W. \& CARR, C. W. (1967). The binding of calcium in mixtures of phospholipids. Proceedings of the Society for Experimental Biology and Medicine 124, I268-1272.

Kawata, T. \& InOUe, T. (I963). Spheroidal and polyhedral forms of Clostridium butyricum induced by penicillin. Journal of Bacteriology 86, I68-170.

Lewis, J. C., SNell, N. L. \& BURR, H. K. (I960). Water permeability of bacterial spores and the concept of a contractile cortex. Science, New York 132, 544-545.

LiNEHAN, D. J. (I966). The effects of various intrinsic factors on the texture of the cooked potato as affected by environmental conditions. Ph.D. thesis, University of East Anglia.

MURReLl, W. G. (1969). Chemical composition of spores and spore structures. In The Bacterial Spore, pp. 21 5-273. Edited by G. W. Gould and A. Hurst. London: Academic Press.

Ogata, S. \& Hongo, M. (1973). Bacterial lysis of Clostridium species. I. Lysis of Clostridium species by univalent cation. Journal of General and Applied Microbiology 19, 25I-26I.

Papahadjopoulos, D. \& OHKI, S. (1969). Stability of asymmetric phospholipid membranes. Science, New York 164, 1075-1077.

PeArCE, S. M. \& FiTz-JAMes, P. C. (I97I). Sporulation of a cortexless mutant of a variant of Bacillus cereus. Journal of Bacteriology 105, 339-348.

Powell, J. F. \& STRANGE, R. E. (I953). Biochemical changes occurring during the germination of bacterial spores. Biochemical Journal 54, 205-209.

RojAS, E. \& ToBIAs, J. M. (1965). Membrane model: association of inorganic cations with phospholipid monolayers. Biochimica et biophysica acta 94, 394-404.

Rondle, C. J. M. \& Morgan, W. T. J. (1955). The determination of glucosamine and galactosamine. Biochemical Journal 61, 586-589. 
SACKS, L. E. (1972). Influence of intra- and extracellular cations on the germination of bacterial spores. In Spores V, pp. 437-442. Edited by H. O. Halvorson, R. Hanson and L. L. Campbell. Washington, D.C.: American Society for Microbiology.

SLEPECKY, R. A. \& Foster, J. W. (1959). Alteration in metal content of spores of Bacillus megaterium and the effect on some spore properties. Journal of Bacteriology 78, I $17-123$.

VARY, J. C. (1973). Germination of Bacillus megaterium spores after various extraction procedures. Journal of Bacteriology 116, 798-802.

VINTER, V., ŠŤASTNÁ, J. \& ČÁSLAVSKÁ, J. (1969). Interference of some cations and basic compounds with the germination and outgrowth of bacterial spores. In Spores IV, pp. 289-297. Edited by L. L. Campbell, Bethesda, Maryland: American Society for Microbiology.

WAITES, W. M. \& WYATT, L. R. (I97I). Germination of spores of Clostridium bifermentans by certain amino acids, lactate and pyruvate in the presence of sodium or potassium ions. Journal of General Microbiology 67, 21 5-222.

Waites, W. M., Wyatt, L. R. \& ARthur, B. (1972). Effect of alkali treatment on the germination and morphology of spores of Clostridium bifermentans. In Spores V, pp. 430-436. Edited by H. O. Halvorson, R. Hanson and L. L. Campbell. Washington, D.C.: American Society for Microbiology.

Warth, A. D., OhYE, D. F. \& MurRell, W. G. (1963a). The composition and structure of bacterial spores. Journal of Cett Biology 16, 579-592.

Warth, A. D., OhYe, D. F. \& MurRell, W. G. $(1963 b)$. Location and composition of spore mucopeptide in Bacillus species. Journal of Cell Biology 16, 593-609.

WyatT, L. R. \& WAITES, W. M. (I97I). Studies with spores of Clostridium bifermentans; comparison of germination mutants. In Spore Research-1971, pp. 123-I3I. Edited by A. N. Barker, G. W. Gould and J. Wolf. London: Academic Press. 